\title{
Effect of Pure Culture Fermentation on Biochemical Composition of Moringa oleifera Lam Leaves Powders
}

\author{
Noumo Ngangmou Thierry ${ }^{1}$, Tatsadjieu Ngouné Léopold ${ }^{2 *}$, Montet Didier ${ }^{3}$, F. Mbofung Carl Moses ${ }^{1}$ \\ ${ }^{1}$ Nationnal School of Agro-Industrial Sciences, Ngaoundéré, Cameroon; ${ }^{2}$ University Institute of Technology, Ngaoundéré, Cameroon; \\ ${ }^{3}$ UMR 95 Qualisud, CIRAD, Montpellier, France. \\ Email: ${ }^{*}$ tatsadjeu@yahoo.fr
}

Received May $20^{\text {th }}, 2013$; revised June 20 ${ }^{\text {th }}, 2013$; accepted June $27^{\text {th }}, 2013$

Copyright (C) 2013 Noumo Ngangmou Thierry et al. This is an open access article distributed under the Creative Commons Attribution License, which permits unrestricted use, distribution, and reproduction in any medium, provided the original work is properly cited.

\begin{abstract}
This study was carried out to determine the effect of the age of the leaves and fermentation on in vitro protein digestibility and biochemical properties of leaves powder of Moringa oleifera. A $6 \times 2 \times 2$ factorial design with two ages of the leaves (one and seven-month-old leaves), six times of fermentation and two fermentation temperatures was used for this purpose. One and seven-month-old fresh leaves were dried at $45^{\circ} \mathrm{C}$ for $24 \mathrm{~h}$, crushed to $1000 \mu \mathrm{m}$ then fermented at $30^{\circ} \mathrm{C}$ and $37^{\circ} \mathrm{C}$ for 120 hours with Lactobacillus plantarum A6 at $10^{8} \mathrm{CFU} / \mathrm{g}$. Samples were withdrawn every 24 hours for physico-chemical analyses. Results showed that 7 month-old leaves were richer in iron, proteins, polyphenols and phytates than one month old leaves. The phytates content dropped from $66.92 \%$ and $61.95 \%$ in the seven and one month-old leaves powders respectively fermented at $37^{\circ} \mathrm{C}$, and from $54.15 \%$ and $67.95 \%$ in the seven and one month-old leaves powders respectively fermented at $30^{\circ} \mathrm{C}$. Protein content increased by $26.34 \%$ and $24.48 \%$ for the $1-$ and 7-month-old leaves powders respectively fermented at $37^{\circ} \mathrm{C}$, and by $13.06 \%$ and $13.97 \%$ for the 1 - and 7 month-old leaves powders respectively, fermented at $30^{\circ} \mathrm{C}$. Iron availability increased from $35.97 \%$ to $40.57 \%$ and $20.74 \%$ to $30.98 \%$ for the 1- and 7-month-old leaves powders respectively, fermented at $37^{\circ} \mathrm{C}$ and from $35.97 \%$ to $39.79 \%$ and $20.76 \%$ to $23.72 \%$ for the 1 - and 7 -month-old leaves powders respectively, fermented at $30^{\circ} \mathrm{C}$. There was a negative correlation between $\mathrm{pH}$, total and reducing sugar contents, time as well as fermentation temperature, whereas there was a positive correlation between total protein content and pepsic digestibility of protein and fermentation time. From these results, fermentation of M. oleifera leaf powder by Lactobacillus plantarum A6 increases protein content, pepsic digestibility of protein and availability of iron and reduces the phytates content of these powders.
\end{abstract}

Keywords: Moringa Oleifera; Leaf Powder; Fermentation; Lactobacillus Plantarum A6; Availability; Protein Digestibility

\section{Introduction}

In recent times malnutrition is still one of the major concerns in developing countries [1]. In Africa, in 2012, there were about 200 million under fed with an increase of $20 \%$ compared to the year 1990 [2]. The analysis of the causes of malnutrition in Africa showed that the most alarming nutritional problems are those of food deficiencies of proteins and micronutrients [3]. Indeed, the diets of many African populations are mainly made up of products of plant origin and often rest on the transformation and consumption of mainly starch-based species [4]. This lack of food diversity often leads to nutritional deficiencies [5]. The reduction of malnutrition thus requires a

"Corresponding author. design of fast solutions of which one is the research of the local resources of plant proteins [3].

In many countries of Africa and Asia, due to its capacity to resist the dryness and their high amounts of nutriaents, Moringa oleifera leaves represent a significant local plant source of nutrients such as proteins, vitamins and minerals [6]. M. oleifera is used in several areas of the world as food and to fight food deficiency diseases or to enrich various foods in proteins, iron, calcium, manganese and zinc [7]. However, although rich in nutrients, $M$. oleifera leaves contain anti-nutritional factors (ANF) in particular phytates, tannins, saponins and fibres [8] which reduce the bioavailability of nutrients [9].

The technological processes such as mechanical, 
thermal, chemical and biological processes are used to reduce ANF content and improve the bioavailability of the nutrients. Among these processes, the biological processes such as fermentation, contrary to thermal, chemical and mechanical processes which can deteriorate quality of food, constitutes an effective means to reduce ANF content of foods [4] and in addition to increase the bioavailability of nutrients, also improves organoleptic and sanitary properties [10] and preservation of food [11].

Among the microorganisms used in food fermentation, lactic bacteria represent the principal group and are found on various substrates [12]. In this group L. plantarum is found in the fermentation of corn pastes [13], sauerkraut, ogi and several other fermented food of vegetable origin [14]. In addition to its abilities to reduce ANF content in food such as phytates due to the production of phytase [15], fibre by the $\beta$-galactosidase [16,17], $L$. plantarum used as ferment increases protein content, bioavailability of nutrients, improves shelf life of food [18-20] and increases the energy density of rich starch foods [21].

As part of main study aimed on improving the nutriational qualities of Moringa oleifera leaves, the present study was carried out to evaluate the effect of fermentation by Lactobacillus plantarum A6 on chemical composition and nutritional properties of Moringa oleifera leaves powder.

\section{Materials and Methods}

\subsection{Raw Material}

The raw material (fresh M. oleifera leaves) was collected at Maroua town (Far-North region of Cameroon) in December 2012. Two groups of leaves were collected: The first group constituted by one (01)-month-old leaves considered in this work as "young leaves". The second group made up with seven (07)-month-old leaves considered as "old leaves".

\subsection{Starter}

L. plantarum A6 was provided by the Microbiology Laboratory of CIRAD Montpellier, France.

\subsection{Production of Leaves Powders}

The fresh leaves of $M$. oleifera were sorted to eliminate the impurities, fade and dead leaves then washed with tap water. Thereafter, these leaves were washed with distilled water and were drained on plastic trays. The leaves were then dried at $45^{\circ} \mathrm{C} \pm 2^{\circ} \mathrm{C}$ for $24 \mathrm{~h}$ in a ventilated hot air dryer (CK2000AUF). The dried leaves were crushed in a hammer mill (standard Culatti, Polymix, Germany) through a sieve mesh of $1000 \mu \mathrm{m}$.

\subsection{Culture of L. plantarum A6}

Stock culture of Lactobacillus plantarum A6 was obtained from UMR of CIRAD Montpellier, France. This strain was propagated in MRS Broth $\left(\mathrm{pH} \mathrm{5.5)}\right.$ at $37^{\circ} \mathrm{C}$ for $16 \mathrm{~h}$. The culture obtained was centrifuged at $6500 \mathrm{rpm}$ for 20 minutes at $4^{\circ} \mathrm{C}$ and the bottom used as starter.

\subsection{Fermentation}

Approximately $200 \mathrm{~g}$ of leaves powder of each age were introduced into glass bottles of $1000 \mathrm{ml}$, and then sterilized at $121^{\circ} \mathrm{C}$ for $20 \mathrm{~min}$. After cooling, the powders were inoculated with L. plantarum A6 at $10^{8} \mathrm{CFU} / \mathrm{g}$. The water content of medium was based on water absorption capacity of powders. The mixtures were homogenized in aseptic condition using a sterile glass rod. Fermentation was carried out at $30^{\circ} \mathrm{C}$ and $37^{\circ} \mathrm{C}$ for 120 hours. Samples without bacteria were set up at each temperature of fermentation as control.

\subsection{Chemicals Analysis}

For the analysis, $50 \mathrm{~g}$ of samples were withdrawn every $24 \mathrm{~h}$ and dried at $45^{\circ} \mathrm{C}$ for 24 hours. Dried fermented and non-fermented powders were analyzed for moisture, proteins, ash and lipids content essentially according to standards methods of the Association of Official Analytical Chemists (AOAC) [22,23]. Powders samples were acid-hydrolyzed and the resulting reducing sugar designnated as available carbohydrates, was determined by the dinitrosalicylic acid (DNS) method of Fisher and Stein [24]. Total sugars were extracted and measured by spectrophotometry using Dubois et al. method [25]. Total protein content was determined by Devani method [26] after sulfuric acid mineralization of samples in presence of selenium catalyst, with a coefficient of conversion of nitrogen into protides of 6.25 . Total lipids were quantified using method described by Bourely [27] and the total iron content using Rodier method [28]. The phytic acid content was estimated using a modified method of McCance and Widdowson as described by Abiodun et al. [29] while the phenolic compounds were estimated by the method of Marigo [30].

In vitro pepsic digestibility of protein (IVPDP) was determined using modified Mertz et al. [31] method. In this procedure $1 \mathrm{~g}$ of sample was mixed with $35 \mathrm{ml}$ of 0.1 $\mathrm{M}$ phosphate buffer with pepsin (1.5 g pepsin/L pH 2.0), incubated for $2 \mathrm{hrs}$ in a shaking water bath at $37^{\circ} \mathrm{C}$ and centrifuged at $10,000 \mathrm{rpm}$ for $15 \mathrm{~min}$. The residue was washed in $10 \mathrm{ml}$ of phosphate buffer and re-centrifuged at $10,000 \mathrm{rpm}$ for 15 minutes. The supernatants were collected and their proteins content's determined by the method of Lowry et al. [32]. The IVPDP was determined as a proportion of soluble proteins after pepsic digestion. 
Iron availability was determined in $1 \mathrm{~mL}$ of supernatant obtained after peptic digestion of one gram of leaf powder according to the method described by Lestienne [4] with some modifications. Practically, $1 \mathrm{~mL}$ of the supernatant of peptic digestion was introduced into a test tube in which was added $1 \mathrm{~mL}$ of hydrochloric acid $(1 \mathrm{~N})$, $0.5 \mathrm{~mL}$ of sodium acetate saturated solution, $0.3 \mathrm{~mL}$ of ascorbic acid and $1 \mathrm{~mL}$ of orthophenantrolin $(0.1 \%)$. The mixture was shaken and heated for $5 \mathrm{~min}$ at $100^{\circ} \mathrm{C}$ in a water bath. After cooling, the volume was completed to $10 \mathrm{ml}$ and the absorbance read at $540 \mathrm{~nm}$ against a blank. The standard curve was carried out using Mohr salt $\left[(\mathrm{NH} 4)_{2}, \mathrm{Fe}(\mathrm{SO} 4)_{2}, 6 \mathrm{H}_{2} \mathrm{O}\right]$.

Water absorption capacity (WAC) of leaves powders was determined according to method of American Association of Cereal Chemist (AACC) 44-1A [33].

\subsection{Statistical Analysis}

The experiment was carried out in triplicate and data obtained were analyzed by analysis of variance in Statistica software [34]. Differences between means were tested using the Duncan Multiple Range Test and correlations between variables were tested using correlation table of Pearson.

\section{Results and Discussion}

\subsection{Chemical Composition and Water Absorption Capacity of $M$. oleifera Leaves Powders}

The results for proximate composition and the Water absorption capacity of M. oleifera are shown in Table 1. The phosphorus, ash, total polyphenol, total lipid and phytates content of $M$. oleifera leaves powders analyzed vary $(\mathrm{p}<0.05)$ according to the age of the leaves.

The increase in phosphorus content from $17.18 \pm 0.71$ $\mathrm{g} / 100 \mathrm{~g}$ DM to $26.57 \pm 1.11 \mathrm{~g} / 100 \mathrm{~g} \mathrm{DM}$, in total polyphenols from $0.92 \pm 0.18 \mathrm{~g} / 100 \mathrm{~g}$ DM to $3.75 \pm 0.84$ $\mathrm{g} / 100 \mathrm{~g} \mathrm{DM}$ and in phytates from $699 \pm 13 \mathrm{mg} / 100 \mathrm{~g} \mathrm{DM}$ to $1182.25 \pm 21.69 \mathrm{~g} / 100 \mathrm{~g} \mathrm{DM}$ were observed from young to old leaves. The ash, lipids and reducing sugars contents decrease respectively from $13.67 \pm 0.33 \mathrm{~g} / 100 \mathrm{~g}$ DM to $12.68 \pm 0.51 \mathrm{~g} / 100 \mathrm{~g} \mathrm{DM} ; 16.091 \pm 0.52$ to $9.34 \pm$ $0.67 \mathrm{~g} / 100 \mathrm{~g}$ DM and from $4.35 \pm 0.025 \mathrm{~g} / 100 \mathrm{~g}$ DM to $3.73 \pm 0.32 \mathrm{~g} / 100 \mathrm{~g}$ DM from young to old leaves. However, dry matter, total sugars and crude fibres contents as well as WAC remain constant in the old and the young leaves powders. Total sugars contents $(13.02 \pm 0.79$ $\mathrm{g} / 100 \mathrm{~g}$ DM and $13.62 \pm 0.54 \mathrm{~g} / 100 \mathrm{~g}$ DM respectively for young and the old leaves powders) are near to those reported by Ray-Yu et al. [35] $(14.47 \pm 2.68 \mathrm{~g} / 100 \mathrm{~g}$ MS and $13.20 \pm 1.98 \mathrm{~g} / 100 \mathrm{~g}$ MS). The phosphorus contents are lower than the value reported by Pallavi and Dipika [36] $(203 \mathrm{mg} / 100 \mathrm{~g})$ obtained in sun dried leaves of
Table 1. Chemical composition and water absorption capacity of powders of $M$. oleifera leaves.

\begin{tabular}{ccc}
\hline & Young (1 month) & Old (7 months) \\
\hline Dry matter (DM) (\%) & $94.85 \pm 0.35^{\mathrm{a}}$ & $94.42 \pm 0.59^{\mathrm{a}}$ \\
Ash (g/100 g DM) & $13.67 \pm 0.33^{\mathrm{a}}$ & $12.68 \pm 0.51^{\mathrm{b}}$ \\
Phosphorus (mg/100 g DM) & $17.18 \pm 0,71^{\mathrm{b}}$ & $26.57 \pm 1.11^{\mathrm{a}}$ \\
Lipids (g/100 g DM) & $16.091 \pm 0.52^{\mathrm{a}}$ & $9.34 \pm 0.67^{\mathrm{b}}$ \\
Reducing sugar (g/100 g DM) & $4.35 \pm 0.02^{\mathrm{a}}$ & $3.73 \pm 0.32^{\mathrm{b}}$ \\
Total sugar (g/100 g DM) & $13.02 \pm 0.79^{\mathrm{a}}$ & $13.62 \pm 0.54^{\mathrm{a}}$ \\
Iron (mg/100 g DM) & $20.34 \pm 0.65 \mathrm{~b}$ & $33.68 \pm 1.22^{\mathrm{a}}$ \\
Polyphenols (g/100 g DM) & $0.92 \pm 0.18^{\mathrm{b}}$ & $3.75 \pm 0.84^{\mathrm{a}}$ \\
Phytate (mg/100 g DM) & $699.00 \pm 13^{\mathrm{b}}$ & $1182.00 \pm 22^{\mathrm{a}}$ \\
Crude fibers (g/100 g DM) & $11.63 \pm 0.84^{\mathrm{a}}$ & $13.02 \pm 0.66^{\mathrm{a}}$ \\
Total protein (g/100 g DM) & $31.62 \pm 2.84^{\mathrm{a}}$ & $35.59 \pm 2.43^{\mathrm{a}}$ \\
WAC (\%) & $572.00 \pm 21^{\mathrm{a}}$ & $579.00 \pm 17^{\mathrm{a}}$ \\
\hline
\end{tabular}

Each value in the table is a mean of 3 replications; Different superscripts in the same line indicate significant differences $(\mathrm{P}<0.05)$.

M. oleifera. On the other hand, the DM content is greater than the value reported by Moyo et al. [37] (90.47\%) on $M$. oleifera leaves powder obtained after air-drying and milling green leaves.

The crude fibres content varied from $11.63 \%$ to $13.02 \%$ respectively for young and old leaves powders. These values are close to those reported by Tchiégang and Aïssatou [38] (12.03\%), but are lower than that found by Price [39] (19.2\%) and Broin [40] (15\%) in $M$. oleifera leaves.

The lipid content of the old-leaves powders $(9.34 \pm$ $0.67 \mathrm{~g} / 100 \mathrm{~g} \mathrm{DM})$ is near to the value reported by Richter et al. [41] (10.6 g/100g DM) on the leaves powder of $M$. oleifera of Niger, but higher compared to lipid content reported by Tchiégang and Aïssatou [38] $(5.17 \pm 0.01 \mathrm{~g} /$ $100 \mathrm{~g} \mathrm{DM})$ in $M$. oleifera leaves collected in the locality of Bini-Dang (Adamawa-Cameroun).

The ANF (total polyphenols and phytates) were more concentrated in the old-leaves powders as shown by Ray-Yu et al. [35]. The young leaves powder has $0.92 \pm$ $0.18 \mathrm{~g} / 100 \mathrm{~g}$ DM of total polyphenol however the oldleaves powder the polyphenol content is $3.75 \pm 0.84 \mathrm{~g} /$ $100 \mathrm{~g}$ DM similar to the value reported by Ray-Yu et al. [35] $(3.06 \pm 0.01 \mathrm{~g} / 100 \mathrm{~g} \mathrm{DM})$. The phytates contents varied from $699 \mathrm{mg} / 100 \mathrm{~g}$ DM in young leaves powder to $1182.25 \mathrm{mg} / 100 \mathrm{~g}$ DM in old leaves powder; values lower than that found by Foidl [42] $(3.1 \mathrm{~g} / 100 \mathrm{~g} \mathrm{DM})$ in those leaves. Amaglo et al. [43] studied the effect of age on chemical composition of $M$. oleifera leaves and showed an increase in protein and phytochemical compounds content in the leaves with the age of the leaves due to 
their accumulation during the growth of plants. However, the differences in nutrients and anti-nutrients contents obtained with others authors would be due to the agroecological differences of the analyzed species, the seasons of harvests or the ages of these leaves.

\subsection{Effect of Fermentation on Physico-Chemical and Nutritional Properties of M. oleifera Leaves Powders}

\subsubsection{Changes in $\mathbf{p H}$}

The changes in the $\mathrm{pH}$ during fermentation of $M$. oleifera leaves powders are presented in Figure 1. The fermentation conditions have a significant effect $(p<0.05)$ on the $\mathrm{pH}$. Fermentation Time, age of leaves, temperature and their interactions influence significantly the $\mathrm{pH}$. Generally, the $\mathrm{pH}$ changes in two phases. In the first phase a slight reduction in the $\mathrm{pH}$ during the first 72 hours of fermentation. This fall goes from 5.8 to 5.4 for old leaves powders fermented at $37^{\circ} \mathrm{C}$ and from 5.8 to 5.2 for young leaves powders fermented at $30^{\circ} \mathrm{C}$. In a second phase, there is an increase in the $\mathrm{pH}$ from the 72 nd hour of fermentation. This increase reaches values of 6.4 for the old leaves powder fermented at $37^{\circ} \mathrm{C}$ and 7.1 for the young leaves powders fermented at $30^{\circ} \mathrm{C}$. The reduction $(\mathrm{p}<$ 0.05 ) in the $\mathrm{pH}$ of the powders during the first 72 hours of fermentation, would be due to a production of organic acids in the medium especially lactic acid resulting from the metabolic activity of L. plantarum A6 [44]. After 72 hours of fermentation, there is a rise in the $\mathrm{pH}$ from the $72^{\text {nd }}$ hour until the end of fermentation (120 Hours). The increase of the $\mathrm{pH}$ observed in this second phase would be due either to the increase of proteins content of the

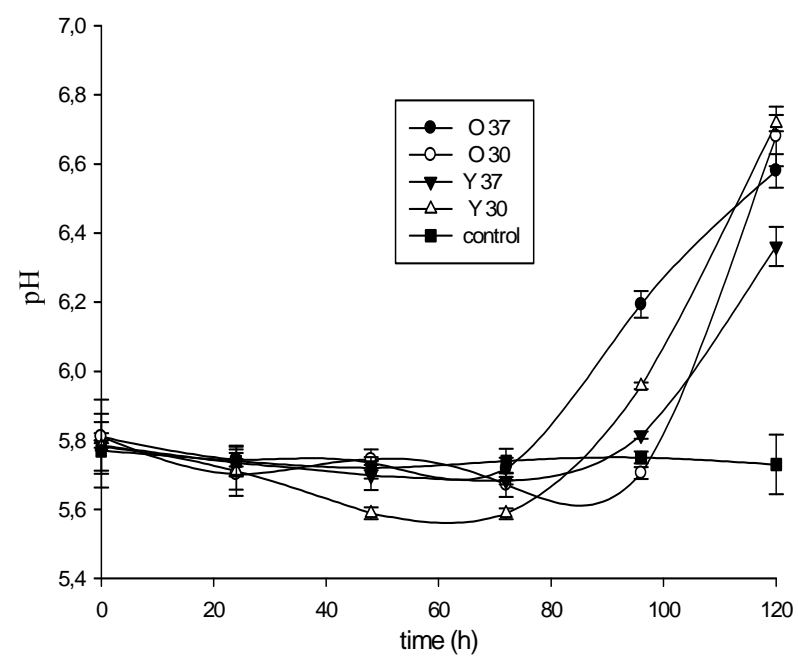

Figure 1. Changes in $\mathrm{pH}$ during fermentation $(\mathrm{O} 37=$ powders of 7-month-old leaves (old) fermented with $37^{\circ} \mathrm{C}$; 030 = powders of 7-month-old leaves (old) fermented with $30^{\circ} \mathrm{C}$, Y37 = powders of leaves of 1 month (young leaves) fermented with $37^{\circ} \mathrm{C}$; Y30 = powders of leaves of 1 month (young leaves) fermented with $30^{\circ} \mathrm{C}$ ). leaves powders or to the proteolytic activities of the lactic bacteria [45], releasing peptides, amino acids and ammonia [46] which increases the $\mathrm{pH}$ of the medium.

\subsubsection{Total Sugars}

The changes in total sugars during fermentation are shown in Figure 2.

There was a drop of total sugars contents from 14.12 $\mathrm{g} / 100 \mathrm{~g}$ DM to $9.39 \mathrm{~g} / 100 \mathrm{~g}$ DM and from $14.12 \mathrm{~g} / 100 \mathrm{~g}$ DM to $10.41 \mathrm{~g} / 100 \mathrm{~g}$ DM for the young leaves powders respectively fermented at $37^{\circ} \mathrm{C}$ and $30^{\circ} \mathrm{C}$. For the old leaves powders, total sugar content varied from 12.73 $\mathrm{g} / 100 \mathrm{~g} \mathrm{DM}$ to $8.52 \mathrm{~g} / 100 \mathrm{~g} \mathrm{DM}$ and from $12.73 \mathrm{~g} / 100 \mathrm{~g}$ $\mathrm{DM}$ to $9.67 \mathrm{~g} / 100 \mathrm{~g} \mathrm{DM}$ when they were fermented respectively at $37^{\circ} \mathrm{C}$ and $30^{\circ} \mathrm{C}$.

The drop of the total sugars contents would be due to their metabolism by L. plantarum A6 during fermentation. Indeed the lactic bacteria use sugars as energy sources during fermentation with production of organic acids [47-49]. Moreover L. plantarum have pectinases $[49,50]$ and $\alpha$-amylase. Thus, there are able to metabolized complex sugars.

\subsubsection{Total Polyphenols}

The changes in total polyphenols during fermentation are shown in Figure 3. There is no significant variation of polyphenols contents during fermentation $(p>0.05)$. However, several authors noticed decrease of polyphenol content during fermentation.

Indeed, Medoua [51] obtained $48.4 \%$ of total poly-

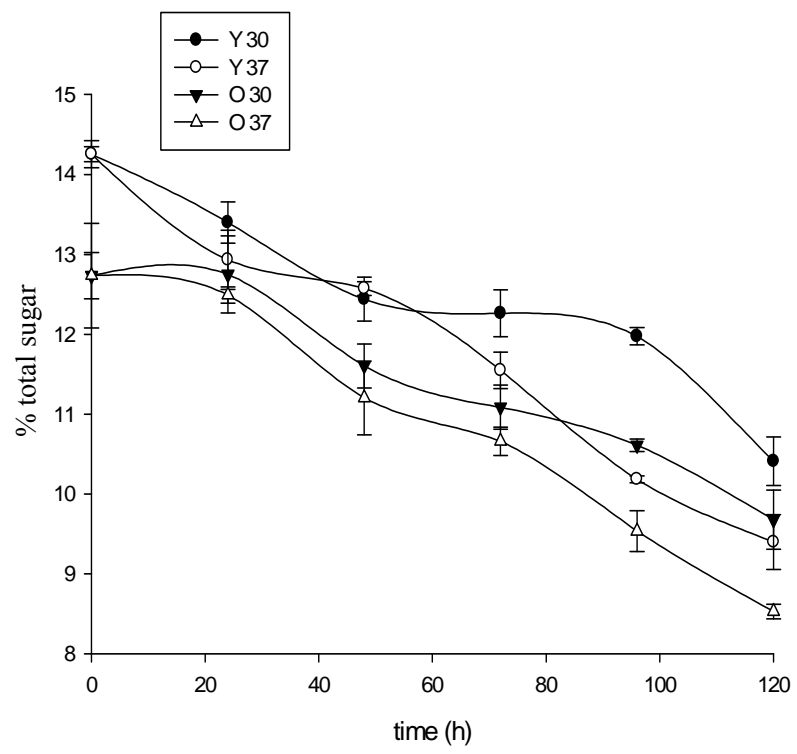

Figure 2. Changes in total sugars during fermentation (O37 $=$ powders of 7 -month-old leaves (old) fermented with $37^{\circ} \mathrm{C}$; O30 = powders of 7-month-old leaves (old) fermented with $30^{\circ} \mathrm{C}, \mathrm{Y} 37=$ powders of leaves of 1 month (young leaves) fermented with $37^{\circ} \mathrm{C}$; Y30 = powders of leaves of 1 month (young leaves) fermented with $30^{\circ} \mathrm{C}$ ). 


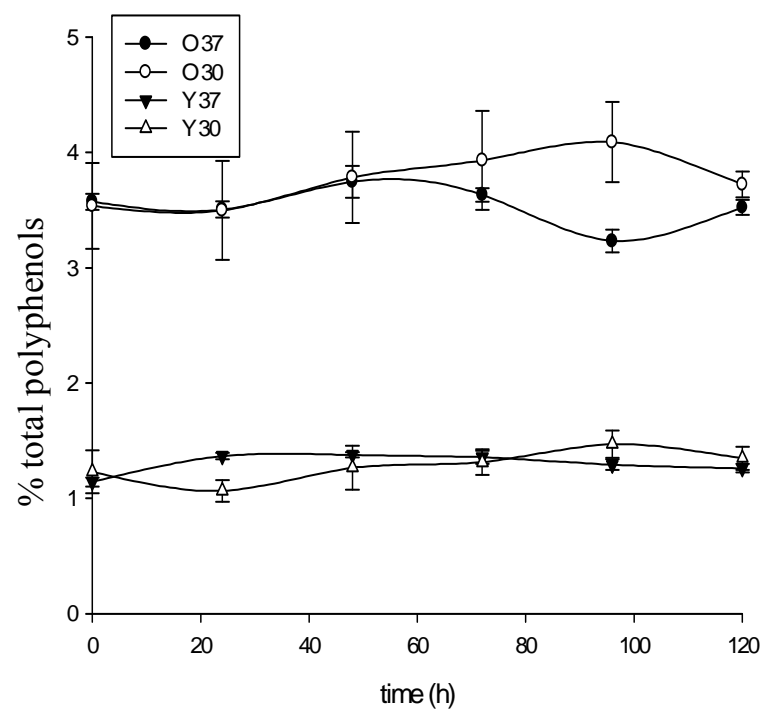

Figure 3. Changes in total polyphenol during fermentation $(037$ = powders of 7-month-old leaves (old) fermented with $37^{\circ} \mathrm{C} ; \mathbf{O} 30$ = powders of 7-month-old leaves (old) fermented with $30^{\circ} \mathrm{C}$, Y37 = powders of leaves of 1 month (young leaves) fermented with $37^{\circ} \mathrm{C}$; Y30 = powders of leaves of 1 month (young leaves) fermented with $30^{\circ} \mathrm{C}$ ).

phenol losses after 14 days of fermentation of the hardened tubers of yams (Dioscorea dumetorum). These differences may result in absence of enzymes responsible of the phenolic compounds hydrolysis during fermentation such as the polyphenols oxydases, peroxidases, laccases. The reduction of the polyphenols contents during the fermentation of food is due to the presence of these enzymes which may be present in food stuff or produce by the micro-organisms during fermentation [4].

\subsubsection{Total Protein}

The evolution of total proteins during fermentation is represented by Figure 4. There is a general increase in total protein content $(\mathrm{p}<0.05)$. However, this increase varies with the age of the leaves and the temperature of fermentation. Increases from $38 \mathrm{~g} / 100 \mathrm{~g}$ DM to $44 \mathrm{~g} / 100 \mathrm{~g}$ $\mathrm{DM}$ for the old leaves powders fermented at $37^{\circ} \mathrm{C}$ and from $33 \mathrm{~g} / 100 \mathrm{~g} \mathrm{DM}$ to $39 \mathrm{~g} / 100 \mathrm{~g} \mathrm{DM}$ for the young leaves powders fermented at $37^{\circ} \mathrm{C}$ were noticed.

The improvement of the protein value of food during fermentation has been reported by several authors [52$55]$.

The increase in the protein content would be due either to the increase in the biomass supported in this case by the $\mathrm{pH}$ of the powders during the fermentation which is in the interval of optimal $\mathrm{pH}$ of the lactic bacteria [13], or the reduction of the amount of dry matter [56] with consumption of component such as sugars.

\subsubsection{Changes in Phytates}

The changes in phytates contents of the different pow- ders during fermentation are shown in Figure 5. The different factors of leaves ages, temperatures of fermentation and fermentation time affect phytates contents $(\mathrm{p}<$ 0.05 ) of powders during fermentation. There is a negative correlation $(p<0.05)$ between the phytates contents, the temperature of fermentation $(r=-0.53)$ and the fer-

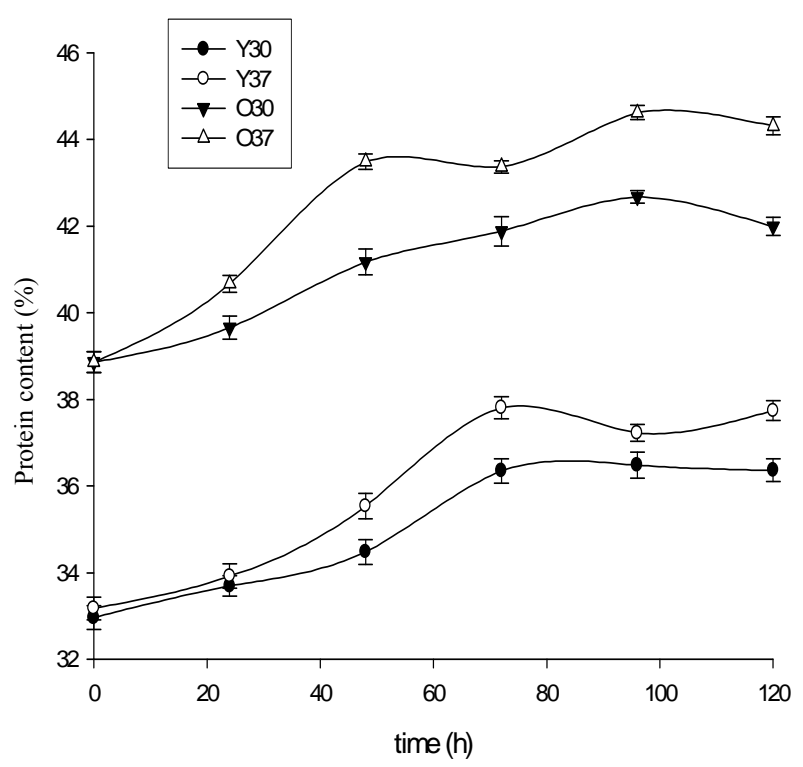

Figure 4. Changes in total protein during fermentation (O37 = powders of 7-month-old leaves (old) fermented with $37^{\circ} \mathrm{C} ; \mathbf{O} 30=$ powders of 7-month-old leaves (old) fermented with $30^{\circ} \mathrm{C}, \mathrm{Y} 37=$ powders of leaves of 1 month (young leaves) fermented with $37^{\circ} \mathrm{C}$; Y30 = powders of leaves of 1 month (young leaves) fermented with $30^{\circ} \mathrm{C}$ ).

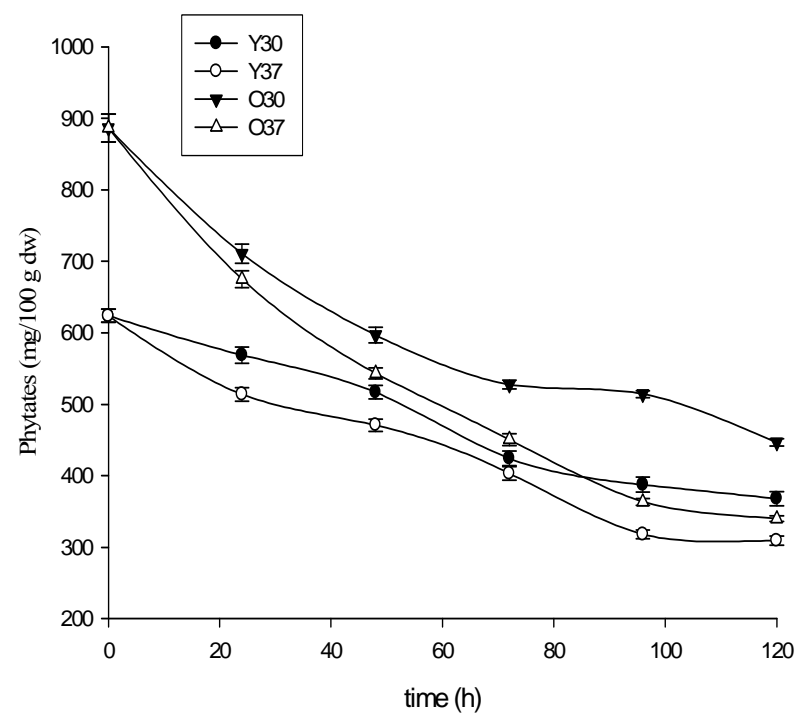

Figure 5. Evolution of phytates contents during fermentation $(037$ = powders of 7 -month-old leaves (old) fermented with $37^{\circ} \mathrm{C}$; $\mathbf{O} 30=$ powders of 7 -month-old leaves (old) fermented with $30^{\circ} \mathrm{C}, \mathrm{Y} 37=$ powders of leaves of 1 month (young leaves) fermented with $37^{\circ} \mathrm{C}$; $\mathrm{Y30}=$ powders of leaves of 1 month (young leaves) fermented with $30^{\circ} \mathrm{C}$ ). 
mentation time $(\mathrm{r}=-0.72)$. A reduction of $66.92 \%$ (from $1182 \mathrm{mg} / 100 \mathrm{~g} \mathrm{DM}$ to $391 \mathrm{mg} / 100 \mathrm{~g} \mathrm{DM}$ ) of phytates contents in old-leaves powders fermented at $37^{\circ} \mathrm{C}$ was noticed whereas a drop was from $1182 \mathrm{mg} / 100 \mathrm{~g}$ DM to $542 \mathrm{mg} / 100 \mathrm{~g}$ DM when the old-leaves powders were fermented at $30^{\circ} \mathrm{C}$. In the young leaves powders, the decrease from $699 \mathrm{mg} / 100 \mathrm{~g} \mathrm{DM}$ to $266 \mathrm{mg} / 100 \mathrm{~g} \mathrm{DM}$ (61.95\%) and from $699.42 \mathrm{mg} / 100 \mathrm{~g}$ DM to $224.76 \mathrm{mg} /$ $100 \mathrm{~g}$ DM were noticed with fermentation at $37^{\circ} \mathrm{C}$ and $30^{\circ} \mathrm{C}$ respectively. Several authors also noted a reduction of phytates contents in fermented food [57-59]. The reduction of phytates contents during fermentation could be allotted to the production of phytases during fermentation by L. plantarum [60].

\subsubsection{In Vitro Pepsic Digestibility of Proteins of M. oleifera Fermented Leaves Powders}

The Figure 6 shows the in vitro peptic digestibility proteins (IVPDP) of $M$. oleifera leaves powders during fermentation. There is a general increase of IVPDP of $M$. oleifera leaves powders during fermentation. The factors age of leaves, temperature and time of fermentation have a significant effect $(\mathrm{p}<0.05)$ on IVPDP. The increases of IVPDP from $34.72 \%$ to $55.46 \%$ and $53.08 \%$ were observed for the young leaves powders respectively fermented at $37^{\circ} \mathrm{C}$ and $30^{\circ} \mathrm{C}$. In the old-leaves powders, the increases were from $39.97 \%$ to $63.97 \%$ and $55.57 \%$ when they were fermented respectively at $37^{\circ} \mathrm{C}$ and $30^{\circ} \mathrm{C}$.

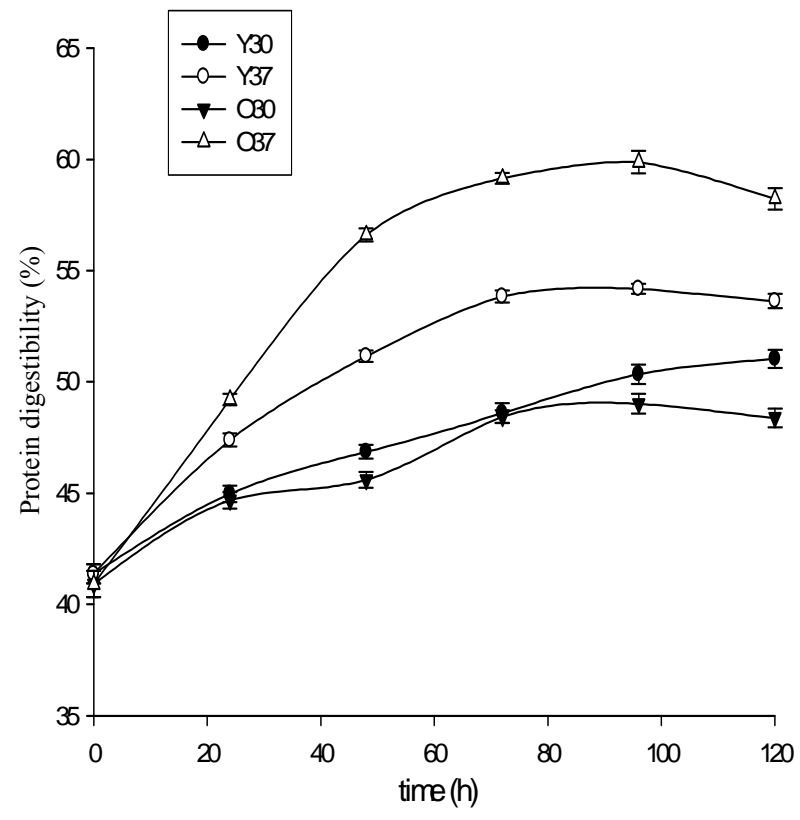

Figure 6. Protein pepsic digestibility during fermentation $(\mathrm{O} 37$ = powders of 7 -month-old leaves (old) fermented with $37^{\circ} \mathrm{C} ; \mathbf{O} 30$ = powders of 7-month-old leaves (old) fermented with $30^{\circ} \mathrm{C}, \mathrm{Y} 37=$ powders of leaves of 1 month (young leaves) fermented with $37^{\circ} \mathrm{C}$; Y30 = powders of leaves of 1 month (young leaves) fermented with $30^{\circ} \mathrm{C}$ ).
The increase in IVPDP express an improvement of protein quality of $M$. oleifera leaves powder during the fermentation. The increase in IVPDP would be due to the drop in ANF contents [4] in particular phytates and to the increase in the protein content. The phytates are responsible to formation of the insoluble complexes with the nutrients such as proteins and minerals [61]. The hydrolysis of the phytates releases proteins from complex and increases their bioavailability.

Indeed, there is a positive correlation $(\mathrm{p}<0.05)$ between the protein content $(r=0.42)$ and IVPDP, but negative correlation between the phytates content $(r=$ $-0.46)$ and IVPDP.

The increase in IVPDP can also result to hydrolysis of proteins to peptide and amino acids by $L$. plantarum A6 used as starter.

\subsubsection{Iron Availability}

The fluctuation of iron availability in the M. oleifera leaves powders during fermentation is presented by Figure 7. There is a general increase of iron availability during fermentation. This increase varies from $21.80 \%$ to $31.12 \%$ and $28.28 \%$ in the young leaves powders respectively fermented at $37^{\circ} \mathrm{C}$ and $30^{\circ} \mathrm{C}$. In old-leaves powders, availability of iron increase from $31.86 \%$ to $52.14 \%$ and

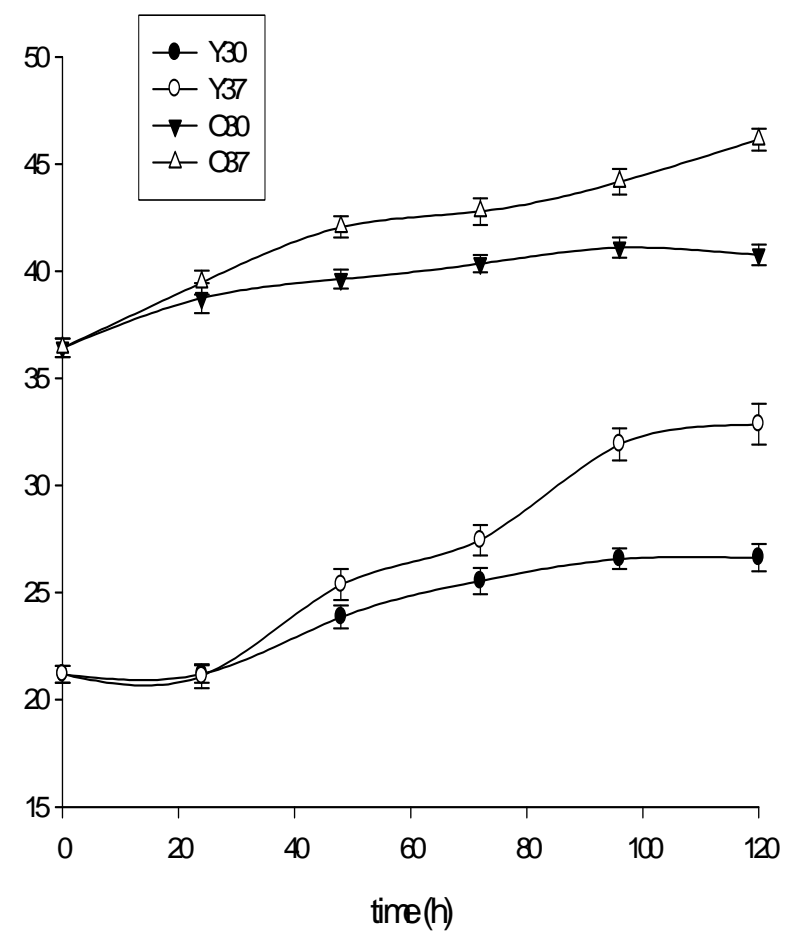

Figure 7. Ion availability of $M$. oleifera fermented leaves powders $(\mathrm{O} 37$ = powders of 7-month-old leaves (old) fermented with $37^{\circ} \mathrm{C}$; O30 = powders of 7 -month-old leaves (old) fermented with $30^{\circ} \mathrm{C}$, Y37 = powders of leaves of 1 month (young leaves) fermented with $37^{\circ} \mathrm{C}$; Y30 = powders of leaves of 1 month (young leaves) fermented with $30^{\circ} \mathrm{C}$ ). 
$47.94 \%$ for fermentations at $37^{\circ} \mathrm{C}$ and $30^{\circ} \mathrm{C}$ respectively. There is a positive correlation $(\mathrm{p}<0.05)$ between time $(\mathrm{r}$ $=0.68)$ the temperature of fermentation $(\mathrm{r}=0.52)$ and iron availability. The increase of iron availability can result to the reduction of phytates content. Indeed, phytic acid is responsible for the reduction of the availability of cations in food, forming insoluble complexes [4]. The hydrolysis of phytic acid release ions thus, allows an increase of minerals availability [59]. There is a negative correlation $(\mathrm{p}<0.05)$ between phytates content $(\mathrm{r}=$ -0.73 ) and iron availability.

Fermentation is known as a process improving iron bioavailability in food of vegetable origin [59,61]. Several authors reported the effect of the reduction of phytates on the increase in the bioavailability of iron. IcardVernière et al. [60] noticed an increase of $31 \%$ of the soluble iron rate in the fermented millet with a reduction of almost $95 \%$ of phytates content. In the same way, an increase of iron bioavailable in fermented sorghum of $3.1 \%$ was reported by Towo et al. [58] during fermentation with a reduction of $88 \%$ of the content of phytates.

\section{Conclusion}

The fermentation of the $M$. oleifera leaves powders by Lactobacillus plantarum A6 reduce the phytates content to $66.92 \%$, increase protein content and their peptic digestibility to a value of $63.97 \%$. Fermentation also increases iron availability in these powders. The fermentation of $M$. oleifera leaves powders allows the improvement of its nutritional qualities. From this work, for the best improvement of nutritional qualities of $M$. oleifera leaf powder, the old leaves must be fermented during 120 hours at $37^{\circ} \mathrm{C}$. These fermented powders thus could be used to fight deficiency malnutrition, a public endemic health problem in the developing countries.

\section{REFERENCES}

[1] R. Bessah and A. Touzi, "Production de Protéines d'Organismes Unicellulaires (P. O. U) à partir des déchets de dattes," Revue Energie Renouvelable, 2001, pp. 37-40.

[2] T. O. Akande and A. A. Odunsi, "Nutritive Value and Biochemical Changes in Broiler Chickens Fed Detoxified Castor Kernel Cake Based Diets," African Journal of Biotechnology, Vol. 11, No. 12, 2012, pp. 2904-2911. doi:10.5897/AJB11.677

[3] K. L. B. Mezajoug, "Propriétés Nutritionnelles et Fonctionnelles des Proteines de Tourteaux, de Concentrats et

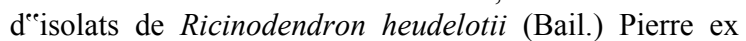
Pax et de Tetracarpidium conophorum (Müll. Arg)," Ph.D. Dissertation, National School of Agro-Industrial Sciences, University of Ngaoundéré, Ngaoundéré, 2010, $170 \mathrm{p}$.

[4] I. Lestienne, "Contribution à L'étude de la Biodisponibilité du fer et du zinc dans le Grain de mil et Conditions
D'amélioration dans les Aliments de Complément," Thesis of Doctorat, Ecole doctorale des Sciences et Procédés Biologiques et Industriels Université, Montpellier, 2004, $224 p$.

[5] M. T. Ruel and M. Harimond, "Diversification Alimentaire, Couverture des Besoins Nutritionnels et Croissance des Enfants: Connaissances Actuelles et Recherches Nécessaires," 2nd International Workshop Food-Based Approaches for a Healthy Nutrition: The Role of Food Technologists and Nutritionists, Ouagadougou, 23-28 November 2003.

[6] Dolcas Biotech, "Moringa oleifera," 2009. http://www.dolcas-biotech.com/pdf/Moringa.pdf

[7] M. Ndong, S. Wade, N. Dossou, T. G. Amadou and R. D. Gning, "Valeur Nutritionnelle du Moringa oleifera, étude de la Biodisponibilite du fer, Effet de l'enrichissement de Divers Plats Traditionnels Sénégalais Avec la Poudre des Feuilles," African Journal of Food Agriculture, Nutrition and Development, Vol. 7, No. 3, 2007, pp. 1-17.

[8] J. W. Fahey, "Moringa oleifera: A Review of the Medical Evidence for Its Nutritional, Therapeutic, and Prophylactic Properties: Part 1," Trees for Life Journal, Vol. 1, No. 5, 2005, pp. 1-15. http://www.tfljournal.org/article.php/2005120112493158 6

[9] R. D. Gning, M. Ndong, S. Wade, N. Dossou and A. T. Guiro, "Valeur Nutritionnelle du Moringa oleifera, étude de la Biodisponibilite du fer, Effet de L'enrichissement de Divers Plats Traditionnels Sénégalais avec la Poudre des Feuilles," African Journal of Food Agriculture, Nutrition and Development, Vol. 7, No. 3, 2007, pp. 1-17.

[10] L. L. Niba. "The Relevance of Biotechnology in the Development of Functional Foods for Improved Nutritional and Health Quality in Developing Countries," African Journal of Biotechnology, Vol. 2, No. 12, 2003. pp. 631635.

[11] R. Shafiur, "Handbook of Food Preservation," 2nd Edition, Taylor and Francis Group, London, 2007, p. 215. doi:10.1201/9781420017373

[12] A. O. Olusegun and G. N. Iniobong, "Spoilage and Preservation of Meat: A General Appraisal and Potential of Lactic Acid Bacteria as Biological Preservatives," International Journal of Biotechnology, Vol. 2, 2011, pp. 3346.

[13] D. Louembé, S. C. Kobawila, G. K. Bouanga and S. Kéléké, "Etude Microbiologique des Feuilles Fermentées de Manioc: 'Ntoba Mbodi'," Tropicultura, Vol. 21, No. 3, 2003, pp. 106-111.

[14] A. A. Yao, M. Egounlety, L. P. Kouame and P. Thonart, "Les Bactéries Lactiques dans les Aliments ou Boissons Amylacés et Fermentés de l'Afrique de l'Ouest: Leur Utilisation Actuelle," Annale de Médécine Vétérinaire, Vol. 153, 2009, pp. 54-65.

[15] M. Zamudio, A. Gonzalez and J. A. Medina, "Lactobacillus plantarum Phytase Activity Is Due to Non-Specific Acid Phosphatase," Letters in Applied Microbiology, Vol. 32, No. 3, 2001, pp. 181-184. doi:10.1046/j.1472-765x.2001.00890.x

[16] E. Giraud, L. Gosselin, B. Marin, J. L. Parada and M. 
Raimbault, "Purification and Characterization of an Extracellular Amylase from Lactobacillus plantarum Strain A6," Journal of Applied Bacteriology, Vol. 75, No. 3, 1993, pp. 276-282. doi:10.1111/i.1365-2672.1993.tb02777.x

[17] J. A. Perumal and J. Kadirvelu, "Screening of Lactobacillus plantarum Isolated from Fermented Idli Batter for Probiotic Properties," African Journal of Biotechnology, Vol. 11, No. 65, 2012, pp. 12856-12864.

[18] D. R. Djoulde, F. X. Etoa, N. J. J. Essia and C. M. F. Mbofung, "Fermentation du Manioc Cyanogène par une Culture Mixte de Lactobacillus plantarum et Rhizopus oryzae," African Journal of Microbiology Research, Vol. 5, No. 27, 2003, pp. 4866-4872.

[19] I. A. Adetunde, A. A. Onilude and L. A. Adetunde, "Effect of Particulate Materials on Lactic Fermentation of New Local White Variety Cassava ('Bianbasse') Using Both Spontaneous and Starter Culture," African Journal of Microbiology Research, Vol. 4, No. 1, 2010, pp. 45-50.

[20] A. Mami, A. R. Hamedi, J. E. Henni, A. Kerfouf and M. Kihal, "Activité antibactérienne de Lactobacillus plantarum isolée du lait cru de chèvre d'Algérie vis à vis de Staphylococcus aureus," Les Technologies De Laboratoire, Vol. 5, No. 21, 2010, pp. 26-31.

[21] L. T. Songré-Ouattara, C. Mouquet-Rivier, C. Icardvernière, I. Rochette, B. Diawara and J. P. Guyot, "Potential of Amylolytic Lactic Acid Bacteria to Replace the Use of Malt for Partial Starch Hydrolysis to Produce African Fermented Pearl Millet Gruel Fortified with Groundnut," International Journal of Food Microbiology, Vol. 130, 2009, pp. 258-264.

[22] Association of Officials Analytical Chemist (AOAC), "Officials Methods of Analysis," 13th Edition, Association of Official Analytical Chemist, Washington DC, 1980.

[23] Association of Officials Analytical Chemist (AOAC), "Officials Methods of Analysis," 15th Edition, Association of Official Analytical Chemist, Washington DC, 1990.

[24] E. H. Fischer and E. A. Stein, "DNS Colorimetric Determination of Available Carbohydrates in Foods," Biochemical Preparations, Vol. 8, 1961, pp. 30-37.

[25] M. Dubois, K. A. Gilles, J. K. Hamilton, P. A. Rebers and F. Smith, "Colorimetric Method for Determination of Sugars and Related Substances," Analytical Chemistry, Vol. 28, No. 3, 1956, pp. 350-356. doi:10.1021/ac60111a017

[26] M. B. Devani, C. J. Shishoo, S. A. Shah and B. N. Suhagia, "Spectrophotometric Method for the Determination of Nitrogen in Kjeldahl Digest," Journal of Analitycal Chemistry, Vol. 72, 1989, pp. 953-956.

[27] J. Bourely, "Observation sur le Dosage de l'Huile des Graines de Cotonnier," Coton et Fibres Tropicales, Vol. 27, No. 2, 1982, pp. 183-196.

[28] J. Rodier, 'L'analyse de l'Eau: Chimie, Physico-Chimie, Bactériologique, Biologie," 6th Edition, Dunod Technique, Paris, 1978, 1136p.

[29] I. S. Abiodun, A. O. Anthony and T. I. Omolara, "Biochemical Composition of Infant Weaning Food Fabricated from Fermented Blends of Cereal and Soybean," Food
Chemistry, Vol. 65, No. 1, 1999, pp. 35-39. doi:10.1016/S0308-8146(98)00132-0

[30] G. Marigo, "Méthode de Fractionnement et d'Estimation des Composes Phénoliques Chez les Végétaux," Analysis, Vol. 2, No. 2, 1973, pp. 106-110.

[31] E. T. Mertz, M. M. Hasen, C. Cairns-Whittern, A. W. Kirleis, L. Tu and J. D. Axtell, "Pepsin Digestibility of Proteins in Sorghum and Other Major Cereals (Improved Pepsin Assay/Processing Effects/Temperature Effects)," Proceedings of the National Academy of Sciences of the USA, Vol. 81, No. 1, 1984, pp. 1-12. doi:10.1073/pnas.81.1.1

[32] O. R. Lowry, N. J. Rosebrough, A. L. Farr and R. J. Randall, "Protein Measurement with the Folin Phenol Reagent," Journal of Biology and Chemistry, Vol. 193, No. 1, 1951, pp. 265-269.

[33] Statsoft, "Statistica for Windows," SPSS Inc., Chicago, 1995.

[34] American Association of Cereal Chemist, "Approved methods of the American Association of Cereal Chemist," AACC, St. Paul, 2000.

[35] Y. Ray-Yu, C. Lien-Chung, H. Jenn-Chung, B. C. W. Brian, C. P. Manuel, M. L. Chadha and V. Levasseur, "Nutritional and Functional Properties of Moringa Leaves-From Germplasm, to Plant, to Food, to Health," Moringa and Other Highly Nutritious Plant Resources: Strategies, Standards and Markets for a Better Impact on Nutrition in Africa, Accra, 16-18 November 2006, pp. 1-9.

[36] J. Pallavi and M. Dipika, "Effect of Dehydration on the Nutritive Value of Drumstick Leaves," Journal of Metabolomics and Systems Biology, Vol. 1, No. 1, 2010, pp. 5-9.

[37] B. Moyo, P. J. Masika, A. Hugo and V. Muchenje, "Nutritional Characterization of Moringa (Moringa oleifera Lam.) Leaves," African Journal of Biotechnology, Vol. 10, No. 60, 2011, pp. 12925-12933.

[38] C. Tchiégang and K. Aissatou, "Données Ethnonutritionnelles et Caractéristiques Physico-Chimiques des Légumes-Feuilles Consommés dans la Savane de L'Adamaoua (Cameroun)," Tropicultura, Vol. 22, No. 1, 2004, pp. 11-18.

[39] D. M. Price, “The Moringa Tree," 2007. http://www.echonet.org

[40] M. Broin, "Composition Nutritionnelle Des Feuilles de Moringa oleifera," 2005. http://www.moringanews. org

[41] N. Richter, P. Siddhuraju and K. Becker, "Evaluation of Nutritional Quality of Moringa (Moringa oleifera Lam.) Leaves as an Alternative Protein Source for Nile Tilapia (Oreochromis niloticus L.)," Aquaculture, Vol. 217, No. 1-4, 2003, pp. 599-611. doi:10.1016/S0044-8486(02)00497-0

[42] N. Foidl, H. P. Makkar and K. Becker, "The Potential of M. oleifera for Agricultural Industrial Uses," In: L. J. Fuglie, Eds., The Miracle Tree: Multiple Attributes of Moringa, CTA/CWS, 2001, pp. 45-76.

[43] N. K. Amaglo, G. M. Timpo, W. O. Ellis and R. N. Bennett, "Effet de L'écartement et la Fréquence des Récoltes sur la Croissance et le Rendement en Feuilles de Moringa 
oleifera Lam," Moringa et Autres Végétaux à Fort Potentiel Nutritionnel: Stratégies, Normes et Marchés Pour un Meilleur Impact sur la Nutrition en Afrique, Atelier International, Accra, 2006, pp. 1-8.

[44] S. Bassa, L. Michodjèhoun-Mestres, V. Anihouvi and J. Hounhouigan, "Prévention de l'Anémie dans les Zones Rurales au Bénin: Aspects Technologiques de la Fortification en fer de la Farine Fermentée de Maïs," 2nd International Workshop Food-Based Approaches for a Healthy Nutrition, Ouagadougou, 2003, pp. 577-588.

[45] S. Sefa-Dedeh, Y. Kluvitse and O. E. Afoakwa, "Influence of Fermentation and Cowpea Steaming on Some Quality Characteristics of Maize-Cowpea Blends," African Journal of Science and Technology, Vol. 2, No. 2, 2001, pp. 71-80.

[46] B. O. Omafuvbe, "Effect of Salt on the Fermentation of Soybean (Glycine max) into daddawa Using Bacillus subtilis as Starter Culture," African Journal of Biotechnology, Vol. 5, No. 10, 2006, pp. 1001-1005.

[47] M .E. El Hag, A. H. El Tinay and N. E. Yousif, "Effect of Fermentation and Dehulling on Starch, Total Polyphenols, Phytic Acid Content and in Vitro Protein Digestibility of Pearl Millet," Food Chemistry, Vol. 77, No. 2, 2002, pp. 193-196. doi:10.1016/S0308-8146(01)00336-3

[48] A. E. A. Yagoub, B. E. Mohamed, A. H. R. Ahmed and A. H. El Tinay, "Study on Furundu, a Traditional Sudanese Fermented Roselle (Hibiscus sabdarifa) Seed: Effect on in Vitro Digestibility, Chemical Composition and Functional Properties of the Total Proteins," Journal of Agriculture and Chemistry, Vol. 52, No. 20, 2004, pp. 61436150. doi:10.1021/jf0496548

[49] D. R. Djoulde, “Mise au Point D'un Ferment Mixte Destine a la Bioconversion Des Tubercules de Manioc Cyanogène," Ph.D. Dissertation, National School of AgroIndustrial Sciences, Ngaoundere University, Ngaoundere, 2005.

[50] D. R. Djoulde, N. J. J. Essia and F. X. Etoa, "Cassava Solid-State Fermentation with a Starter Culture of Lactobacillus plantarum and Rhyzopus oryzae for Cellulase Production," African Journal of Microbiology Research, Vol. 5, No. 27, 2011, pp. 4866-4872.

[51] N. J. M Medoua, "Potentiels Nutritionnel et Technologique Des Tubercules Durcis de L'igname, Dioscorea dumetorum (Kunth) Pax: étude du Durcissement PostRécolte et Des Conditions de Transformation Des Tubercules Durcis en Farine," Ph.D. Dissertation, National School of Agro-Industrial Sciences, Ngaoundere University, Ngaoundere, 2005.

[52] F. S. Ibrahim, E. E. Babiker, N. E. Yousif and A. H. El Tinay, "Effect of Fermentation on Biochemical and Sensory Characteristics of Sorghum Flour Supplemented with Whey Protein," Food Chemistry, Vol. 92, No. 2, 2005, pp. 285-292. doi:10.1016/j.foodchem.2004.07.024

[53] P. Azokpota, D. J. Hounhouigan and M. C. Nago, "Microbiological and Chemical Changes during the Fermentation of African Locust Bean (Parkia biglobosa) to Produce Afitin, Iru and Sonru, Three Traditional Condiments Produced in Benin," International Journal of Food Microbiology, Vol. 107, No. 3, 2006, pp. 304-309. doi:10.1016/j.ijfoodmicro.2005.10.026

[54] T. I. Mbata, M. J. Ikenebomeh and S. Ezeibe, "Evaluation of Mineral Content and Functional Properties of Fermented Maize (Zea mays) Flour Blended with Bambara Groundnut (Vigna subterranean L.)," African Journal of Food Science, Vol. 13 No. 4, 2009, pp. 107-112.

[55] B. Opere, O. O. Aboaba, E. O. Ugoji and B. A. Iwalokun, "Estimation of Nutritive Value, Organoleptic Properties and Consumer Acceptability of Fermented Cereal Gruel (OGI)," Advance Journal of Food Science and Technology, Vol. 4, No. 1, 2012, pp. 1-8.

[56] M. R. Mona, E. M. Abeer, M. A. Hala and U. N. Mohamed, "Improvement of Nutritional Quality and Antioxidant Activities of Yeast Fermented Soybean Curd Residue," African Journal of Biotechnology, Vol. 10, No. 28, 2011, pp. 5504-5513.

[57] N. L. Tatsadjieu, F.-X. Etoa and C. M. F. Mbofung, "Drying Kinetics, Physico-Chemical and Nutritional Characteristics of 'Kindimu', a Fermented Milk-Based-Sorghum-Flour," The Journal of Food Technology in Africa, Vol. 9, No. 1, 2004, pp. 17-22.

[58] E. Towo, E. Matuschek and U. Svanberg, "Fermentation and Enzyme Treatment of Tannin Sorghum Gruels: Effects on Phenolic Compounds, Phytate and in Vitro Accessible Iron," Food Chemistry, Vol. 94, No. 3, 2006, pp. 369-376. doi:10.1016/j.foodchem.2004.11.027

[59] M. O. Nuha, A. M. A. Isam and E. B Elfadil, "Chemical Composition, Antinutrients and Extractable Minerals of Sicklepod (Cassia obtusifolia) Leaves as Influenced by Fermentation and Cooking," International Food Research Journal, Vol. 17, 2010, pp. 775-785.

[60] C. Icard-Vernière, V. Greffeuille, B. Caporiccio, S. Trèche and $\mathrm{P}$. Besançon, "Influence du Trempage, de la Germination, de la Fermentation et de l'Ajout de Phytases Sur la Biodis-Ponibilité du Fer et du Zinc dans les Farines de Mil," 2nd International Workshop FoodBased-Approaches for a Healthy Nutrition Ouagadougou, 2003, pp. 427-436

[61] O. Nam-Soon and I. Man-Jin, "Phytate Degradation by Leuconostoc mesenteroides KC51 Cultivation in Soymilk," African Journal of Biotechnology, Vol. 8, No. 13, 2009, pp. 3023-3026. 